\title{
Modelling the effect of conservation measures on potential soil erosion: a USLE and GIS approach
}

\author{
Vipul Shinde $^{1, *}$, Manjushree Singh ${ }^{1}$, Sachin Nandgude ${ }^{2}$ and Birendra Bharti ${ }^{3}$ \\ ${ }^{1}$ Department of Agricultural Engineering, Navsari Agricultural University, Navsari 396 450, India \\ ${ }^{2}$ Department of SWCE, Mahatma Phule Krishi Vidyapeeth, Rahuri 413 722, India \\ ${ }^{3}$ Centre for Water Engineering Management, Central University of Jharkhand, Brambe 835 205, India
}

\begin{abstract}
Quantitative assessment of soil loss in Ambika watershed, Gujarat, India was done using universal soil loss equation (USLE) and geographic information system (GIS) to analyse spatial distribution of soil loss. The annual average soil loss for the entire watershed was estimated at 22.41 tonne $\mathrm{ha}^{-1}$ year $^{-1}$, which substantially contributes to low agricultural productivity of the area. About $80 \%$ of the watershed area is affected by moderately high to very high soil erosion ( $>15$ tonne $\mathrm{ha}^{-1}$ year $^{-1}$ ) and requires immediate attention for soil conservation measures. The average slope of micro-watersheds in this area varies between $5 \%$ and $8 \%$. So, according to recommendations of land capability classification for class IV lands, contour bunds and terraces were selected as soil conservation measures, which resulted in the reduction of annual average soil erosion of the entire watershed to 17 tonne $\mathrm{ha}^{-1}$ year $^{-1}$. Therefore, these conservation measures can be effectively applied in watersheds with similar geomorphology and average slope up to $8 \%$, to reduce soil erosion. The cumulative effect of soil conservation measures indicated that area affected by soil erosion magnitude under priority class 1 was reduced from $7.5 \%$ to $0 \%$; under priority class 2 it reduced from $49.75 \%$ to $37.19 \%$, and for priority class 3 the area reduced from $22.41 \%$ to $\mathbf{1 7 . 6 3 \%}$. Hence, determination and monitoring of soil erosion and subsequent planning of soil conservation practices for improving agricultural productivity can be effectively achieved using USLE and GIS technology.
\end{abstract}

Keywords: Agricultural productivity, conservation measures, soil erosion, mathematical modelling, watershed area.

AGRICULTURE is the major source as well as a victim of non-point source pollution, and sediment is its most important ingredient along with pesticides and fertilizers. Thus, identification of critical areas based on soil erosion hazard and implementation of best management practices

*For correspondence. (e-mail: vipulshinde123@gmail.com) is essential for successful soil conservation programmes. In the process of erosion, soil particles get detached and are transported from one location to other due to the impact of water ${ }^{1}$. It is influenced by disturbance of topsoil as well as roughness of the surface. Almost $50 \%$ of topsoil on earth has been eroded in past 150 years ${ }^{2}$, which has affected soil availability and soil-carrying capacity ${ }^{3-5}$. Spatial variations of soil erosion play a significant role in analysing erosion intensity and deciding soil and water conservation structures for a particular location. Intensive agricultural practices have a significant effect on soil properties, which help reduce soil loss mainly in steepslope areas $^{6}$. Rich productive topsoil gets eroded from catchment areas that affects crop production; subsequently the eroded soil gets deposited in rivers, lakes and reservoirs resulting in reduction of reservoir capacity and degradation of water quality ${ }^{7,8}$. Soil erosion at watershed scale can be estimated using numerous empirical models $^{9,10}$. The sediment yield index method proposed by Bali and Karale $^{11}$ and universal soil loss equation (USLE) by Wischmeier and $\mathrm{Smith}^{12}$ are widely used for the estimation of soil erosion. USLE has been extensively applied at the watershed scale on the basis of lumped approach $^{13,14}$ to catchment scale ${ }^{7,15,16}$.

Ambika watershed in Dang district of southern Gujarat region experiences heavy rainfall. Soil loss is the major cause of concern for rich biodiversity in general and agriculture in particular in this region. Therefore, estimation of soil loss at watershed scale is necessary, but difficult to carry out due to undulating topography, heavy rainfall and inaccessible areas in this region. It is essential to estimate soil loss from the watershed for planning and execution of soil and water conservation measures, and suggesting best management practices (BMPs) for a particular watershed. Advent of new technologies and tools like remote sensing and geographical information system (GIS) has been proven to be beneficial in the collection of more accurate information from any region and better analysis of the same ${ }^{17-19}$. Therefore, natural resources management has become relativity easier and faster in many parts of the world. So it is prudent to use these technologies and tools for better planning 
and development of watersheds to increase crop productivity.

\section{Materials and method}

The study area, viz. Ambika watershed in southern Gujarat, lies between $20^{\circ} 34^{\prime}-20^{\circ} 54^{\prime} \mathrm{N}$ lat. and $73^{\circ} 25^{\prime}-73^{\circ} 53^{\prime} \mathrm{E}$ long. covering a geographical area of 830.5 sq. km (Figure 1). The cloud-free satellite image (Landsat ETM+ imagery) was acquired from the Global Land Cover Facility, whereas ASTER DEM of $30 \mathrm{~m}$ resolution was acquired from Earth Remote Sensing Data Analysis Center (ERSDAC), Japan. Monthly rainfall data during 1984 to 2013 were collected from India Meteorological Department (IMD), Waghai. Soil analysis data were collected from Krishi Vigyan Kendra (KVK) Waghai, Gujarat, based on which soil map of the study area was prepared.

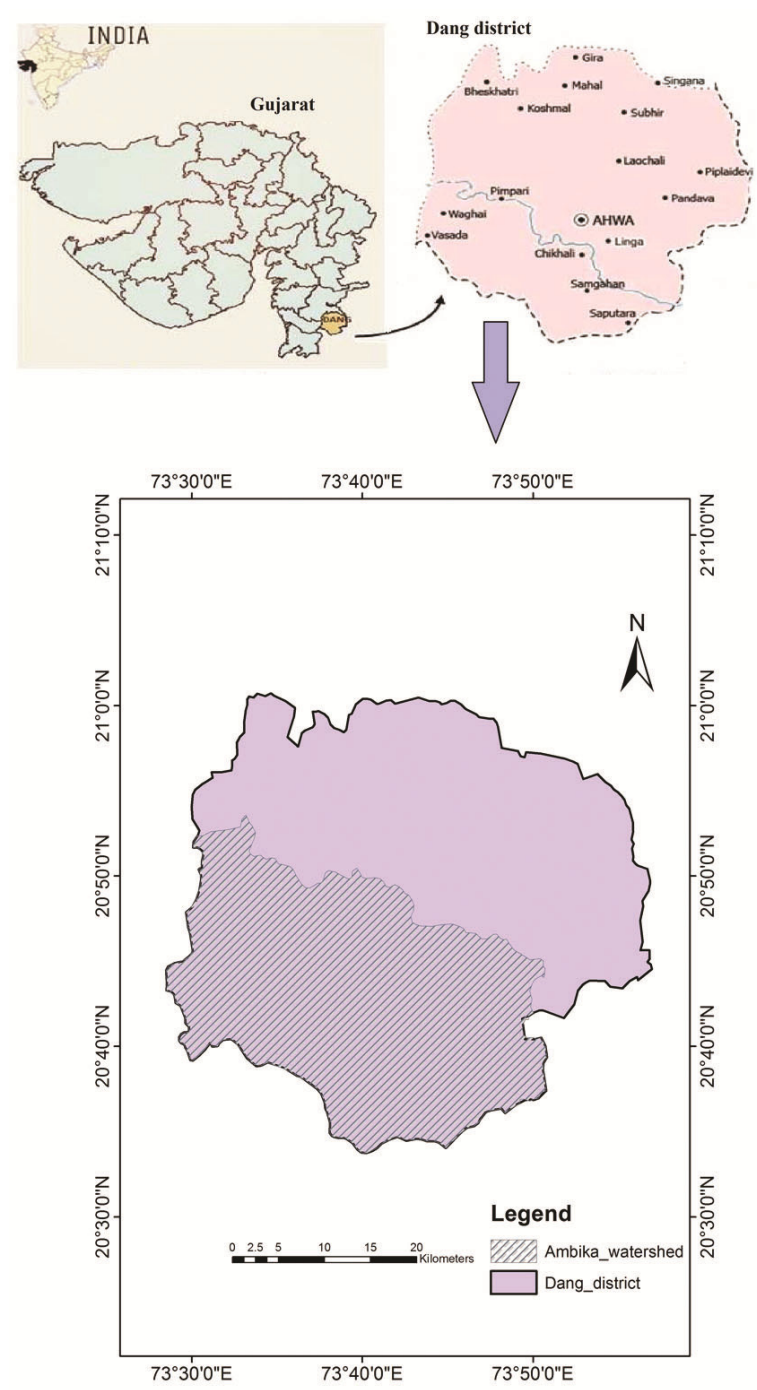

Figure 1. Location of Ambika watershed, Gujarat, India.

\section{Model description}

Average annual soil loss from a catchment can be estimated using USLE, which depends on rainfall erosivity, soil erodability, slope length and steepness factor, cover management and conservation practice factor. USLE has been widely applied for various areas comprising agricultural and forest watersheds, range land, hilly land, rugged terrain and degraded lands for predicting average annual soil loss ${ }^{20,21}$. The average annual soil loss was estimated using the following USLE (eq. (1) $)^{21}$.

$$
A=R \times K \times L \times S \times C \times P,
$$

where $A$ is the average annual soil loss (tonne ha ${ }^{-1}$ ), $R$ the rainfall erosivity factor, $K$ the soil erodibility factor, $L$ the slope length factor, $S$ the slope steepness factor, $C$ the cover and management factor and $P$ is the conservation practice factor. The thematic layers of all these factors were prepared in ArcGIS 10.3 to quantify the average annual soil loss of Ambika watershed ${ }^{22}$.

\section{Results and discussion}

\section{Rainfall erosivity factor}

The $R$-factor indicates the potential ability of rainfall to cause soil erosion at a particular location. It is calculated as the product of total storm energy and its maximum $30 \mathrm{~min}$ intensity ${ }^{12}$. The average annual rainfall of 30 years (1984-2013) was estimated as $1833 \mathrm{~mm}$. In this study, $R$-factor was estimated using the formula given by Choudhury and Nayak ${ }^{23}$.

$$
R=79+0.363 X_{a}
$$

where $R$ is the rainfall erosivity and $X_{a}$ is the average annual rainfall $(\mathrm{mm})$.

\section{Soil erodibility factor}

The $K$-factor indicates the susceptibility of soil particles to detach and be transported from one location to other. The ability of soil to resist erosion depends on its physiochemical properties and thus the $K$-factor value varies with different soil types. Soil analysis data of ten locations collected from KVK Waghai were used for the estimation of $K$-factor using the equation given by Wischemer et al. ${ }^{24}$.

$$
\begin{aligned}
100 \mathrm{~K}= & 2.1 \mathrm{M}^{1.14}\left(10^{-4}\right)(12-a) \\
& +3.25(b-2)+2.5(c-3),
\end{aligned}
$$

where $K$ is the soil erodibility factor, $M=(\%$ silt $+0.7 \%$ sand) $\times(100-\%$ clay $), a$ the organic matter content, $b$ 


\section{RESEARCH ARTICLES}

the structure of soil and $c$ is the permeability of soil. $\%$ OM (organic matter) was estimated as $(1.724 \times \%$ organic carbon). Point map was prepared for these ten sampling stations in ArcGIS and value of $K$-factor is assigned to each station. Further, using raster interpolation technique, the $K$-factor map for Ambika watershed was prepared (Figure 2).

\section{Slope length factor}

The $L S$-factor indicates the combined effect of slope steepness and slope length on the rate of soil erosion. Steep and long slope produces high flow velocity and corresponding high surface run-off, thereby contributing more to soil erosion ${ }^{25}$. The $L S$-factor was computed using the following equation given by Wischmeier and Smith ${ }^{12}$.

$$
\begin{aligned}
L S= & ((\text { Flow accumulation }) \times(\text { cell size }) / 22.13)^{m} \\
& \times\left(0.065+0.045 S+0.0065 S^{2}\right),
\end{aligned}
$$

where $S$ is the slope (\%) was derived from digital elevation model (DEM) of Ambika watershed and the value of $m$ is based on slope categories. Flow accumulation was derived from DEM after performing fill and flow direction processes using ArcHydro tool in ArcGIS 10.2. Figure 3 shows the DEM and $L S$-factor map of Ambika watershed.

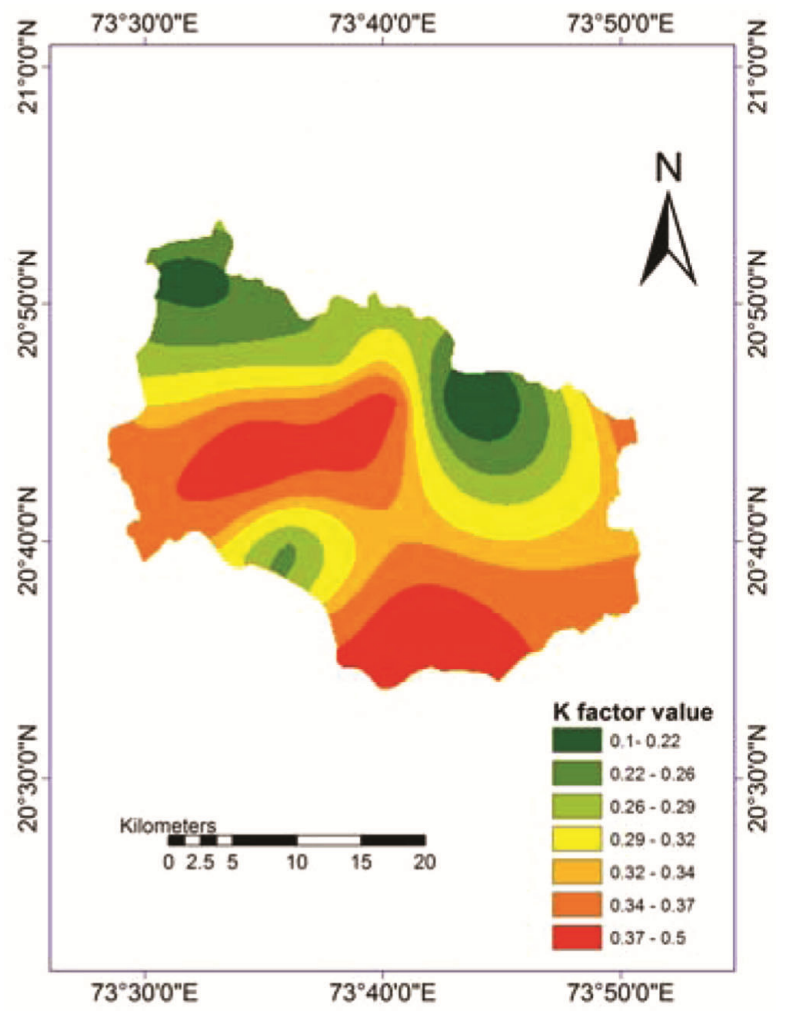

Figure 2. $K$-factor map of Ambika watershed.

\section{Cover and management factor}

The $C$-factor represents the effect of vegetation cover which prevents soil erosion by reducing raindrop velocity during rainfall. The amount of energy dissipated by vegetation depends upon percentage and type of vegetation cover. In the present study, the $C$-factor values suggested by $\mathrm{USDA}^{26}$ and applied by Kayet et $a .^{27}$ and Pancholi et $a{ }^{28}$ for Indian conditions were used (Table 1). The Landsat image was classified in five different land-use (LU) classes: agriculture land, barren land, built-up land, forest and water bodies (Figure 4) with the help of ground truth data (Figure 4). Table 1 shows the area under various LU class and their corresponding $C$-factor values.

\section{Conservation practices factor}

The $P$-factor represents the ratio of soil loss from a field with the given conservation practice to that where no conservation is practised. The control practice reduces the rate of soil erosion by influencing drainage patterns, concentration, velocity and hydraulic forces of run-off ${ }^{21}$. The Landsat image was classified and pixels of each LU class was assigned a $P$-value, as suggested in the United States Department of Agriculture (USDA) Handbook (Table 1) ${ }^{29}$.

\section{Average annual soil loss using USLE}

Thematic layers of $R$-, $K$-, $L S$-, $C$ - and $P$-factors were generated in ArcGIS and the product of these layers gives the average annual soil loss $(A)$ for Ambika watershed (Figure 5). A layer of annual soil loss was overlaid with the micro-watershed map which contains 64 microwatersheds to obtain the micro-watershed-wise soil loss (Figure 5), which was further classified in different soil erosion classes $^{30}$ (Table 2). The amount of average annual soil loss at micro-watershed level ranged between 4.5 and 52.24 tonne $\mathrm{ha}^{-1}$ year $^{-1}$. The study shows that about $50 \%$ of the area falls under high risk of soil erosion, whereas $18 \%$ of the area has moderate and $22 \%$ has moderately high risk of soil erosion (Table 2). Priority fixation was done on the basis of average annual soil loss of microwatersheds.

\section{Best management practices}

Adoption of BMPs is required to reduce sediment yield, and run-off rate after deciding the priority of a microwatershed. Various types of BMPs can be suggested to control soil loss for the highest priority microwatersheds. BMPs are not exactly the same for all microwatersheds; they vary according to geomorphology of the micro-watersheds. BMPs like afforestation, trenching, bunding, terracing, vegetative barriers, sediment basin, 


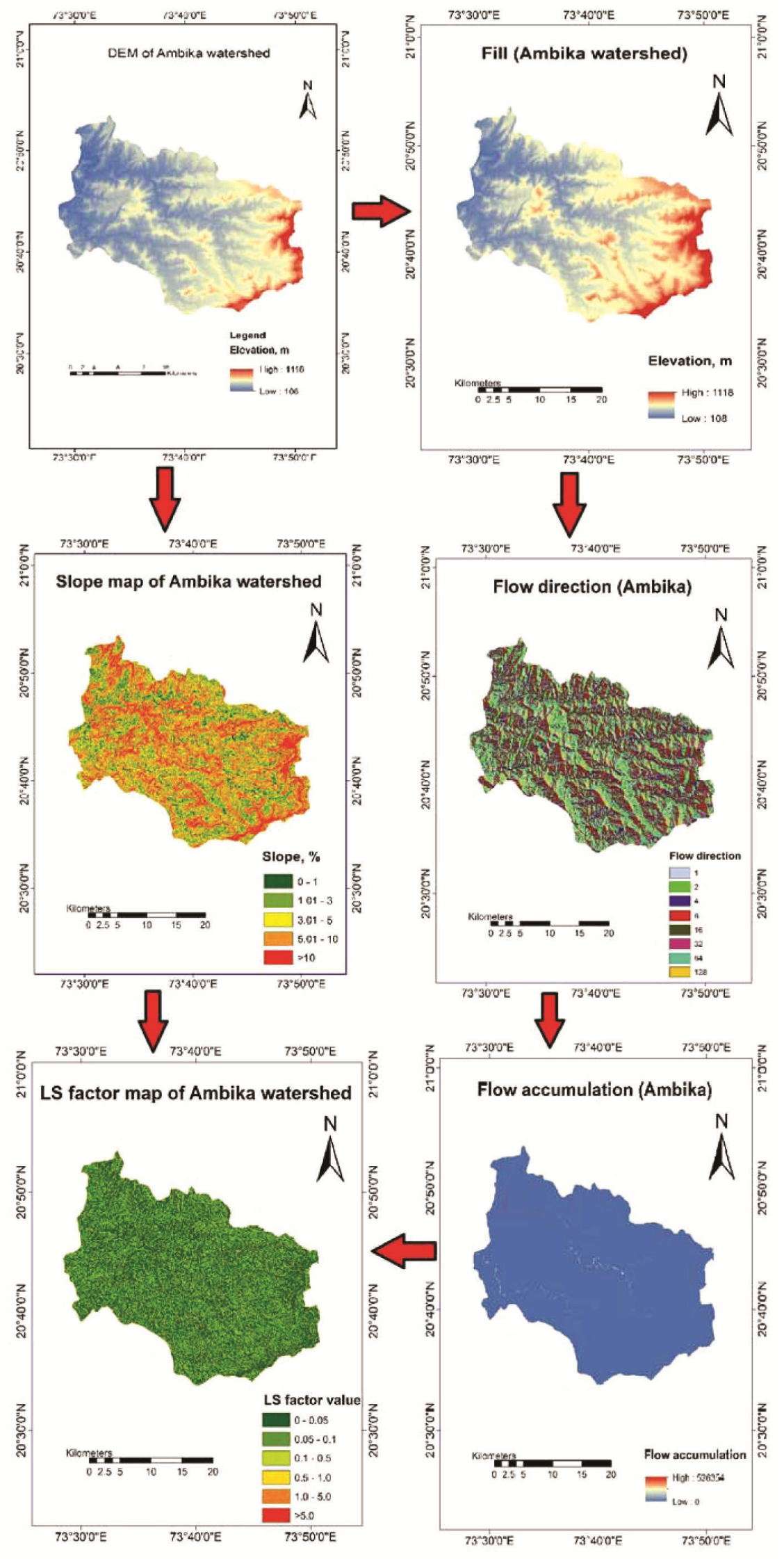

Figure 3. LS-factor map of Ambika watershed. 
Table 1. Area and $C$-factor value under different land use land cover (LULC) classes

\begin{tabular}{lccccc}
\hline Land use & Agriculture land & Barren land & Built-up land & Forest & Water bodies \\
\hline Area (\%) & 16.24 & 2.11 & 7.15 & 70.10 & 4.40 \\
$C$-factor & 0.5 & 0.8 & 0.2 & 0.04 & 0 \\
$P$-factor & 0.5 & 1.0 & 1.0 & 1.0 & 1.0 \\
\hline
\end{tabular}

Table 2. Percentage of area under different erosion classes

\begin{tabular}{llrrr}
\hline $\begin{array}{l}\text { Soil erosion } \\
\left.\text { (tonne } \mathrm{ha}^{-1} \text { year }^{-1}\right)\end{array}$ & Erosion class & $\begin{array}{c}\text { Area } \\
(\mathrm{sq} . \mathrm{km})\end{array}$ & $\begin{array}{c}\text { Area } \\
(\%)\end{array}$ & $\begin{array}{c}\text { No. of } \\
\text { micro-watersheds }\end{array}$ \\
\hline $0-5$ & Very low & 10.56 & 1.27 & 1 \\
$5-10$ & Low & 9.98 & 1.20 & 1 \\
$10-15$ & Moderate & 148.29 & 17.85 & 12 \\
$15-20$ & Moderately high & 186.16 & 22.41 & 15 \\
$20-40$ & High & 413.24 & 49.75 & 32 \\
$>40$ & Very high & 62.32 & 7.50 & 3 \\
& Total & 830.50 & 100 & 64 \\
\hline
\end{tabular}

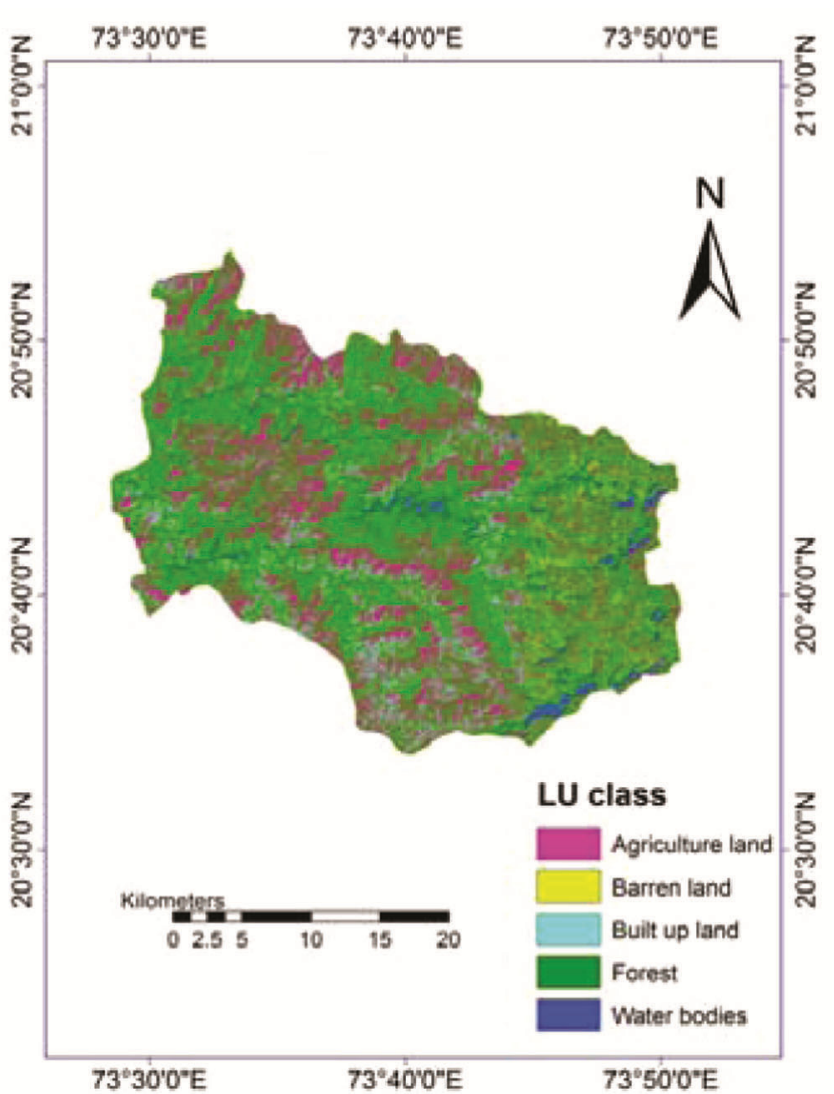

Figure 4. Land-use map of Ambika watershed.

bendway weir and different kinds of check dams are selected in different studies. In the present study, BMPs were decided on the basis of mean slope of the microwatershed and corresponding soil erosion magnitude. It was observed that soil erosion is mostly affected by slope of the micro-watershed. With increase in average slope of a micro-watershed, soil loss increases (Table 3). The micro-watersheds which come under moderate to very high category ( soil erosion $>10$ tonne ha $^{-1}$ year $^{-1}$ ) were considered for soil conservation treatments and incorporated in BMPs of Ambika watershed.

Soil erosion can be tackled by planning a suitable cropping system based on erosion hazard in order to improve soil health and its preservation. To develop a scientific programme of management, the Soil Conservation Service (SCS) of USDA has done pioneering work on land capability classification $^{31}$. Accordingly, land is broadly classified in two groups-land suited for cultivation comes under group 1 and land not suited for cultivation under group 2 (ref. 32). Each group is again divided into four classes. 'Group 1 lands' comprise of 'land classes I-IV' which are cultivable and 'group 2 lands' comprise of 'land classes V-VIII' which are non-cultivable. Accordingly, if per cent slope of land varies from 5 to 8 , it comes under class IV and soil conservation measures like contour bunds or terraces and intense agronomical measures may be adopted in such areas ${ }^{32}$. In the present study, the average slope of all micro-watersheds selected for soil conservation treatments varies from $5 \%$ to $8 \%$. So, conservation measures like contour bunds and terraces were selected in these micro-watersheds to reduce soil erosion. Accordingly, the $P$-factor values of 0.5 for contour bunds and 0.1 for terracing were incorporated ${ }^{33}$ and soil erosion was estimated keeping other factors $(R, K, L S$ and $C$ ) the same.

The cumulative effect of conservation measures on soil erosion for priority classes $1-3$ is reduction in the area affected by average soil erosion magnitude from $7.5 \%$ to $0 \%$ for priority class $1,49.75 \%$ to $37.19 \%$ for priority class 2 , and $22.41 \%$ to $17.63 \%$ for priority class 3 (Tables 3 and 4). Figure 6 shows soil erosion map of Ambika watershed after incorporating BMPs. It can be observed from Figure 6 that the number of micro-watersheds in 
Table 3. Mean slope and number of watersheds in the respective erosion classes

\begin{tabular}{llccc}
\hline $\begin{array}{l}\text { Soil erosion } \\
\left(\text { tonne ha } \text { year }^{-1}\right)\end{array}$ & \multicolumn{1}{c}{ Erosion class } & $\begin{array}{c}\text { Mean slope } \\
(\%)\end{array}$ & No. of MWs & $\begin{array}{c}\text { Priority } \\
\text { class }\end{array}$ \\
\hline $10-15$ & Moderate & 5.46 & 12 & 4 \\
$15-20$ & Moderately high & 5.54 & 15 & 3 \\
$20-40$ & High & 6.08 & 32 & 2 \\
$>40$ & Very high & 7.83 & 3 & 1 \\
\hline
\end{tabular}

Table 4. Percentage of area under different erosion classes after incorporating best management practices

\begin{tabular}{llccc}
\hline $\begin{array}{l}\text { Soil erosion } \\
\left(\text { tonne }^{-1} \text { year }^{-1}\right)\end{array}$ & Erosion class & $\begin{array}{c}\text { Area } \\
(\text { sq. km) }\end{array}$ & $\begin{array}{c}\text { Area } \\
(\%)\end{array}$ & $\begin{array}{c}\text { No. of } \\
\text { MWs }\end{array}$ \\
\hline $0-5$ & Very low & 13.19 & 1.59 & 2 \\
$5-10$ & Low & 29.31 & 3.53 & 3 \\
$10-15$ & Moderate & 332.75 & 40.06 & 25 \\
$15-20$ & Moderately high & 146.45 & 17.63 & 12 \\
$20-40$ & High & 308.85 & 37.19 & 22 \\
$>40$ & Very high & 0.00 & 0.00 & 0 \\
& Total & 830.50 & 100 & 64 \\
\hline
\end{tabular}
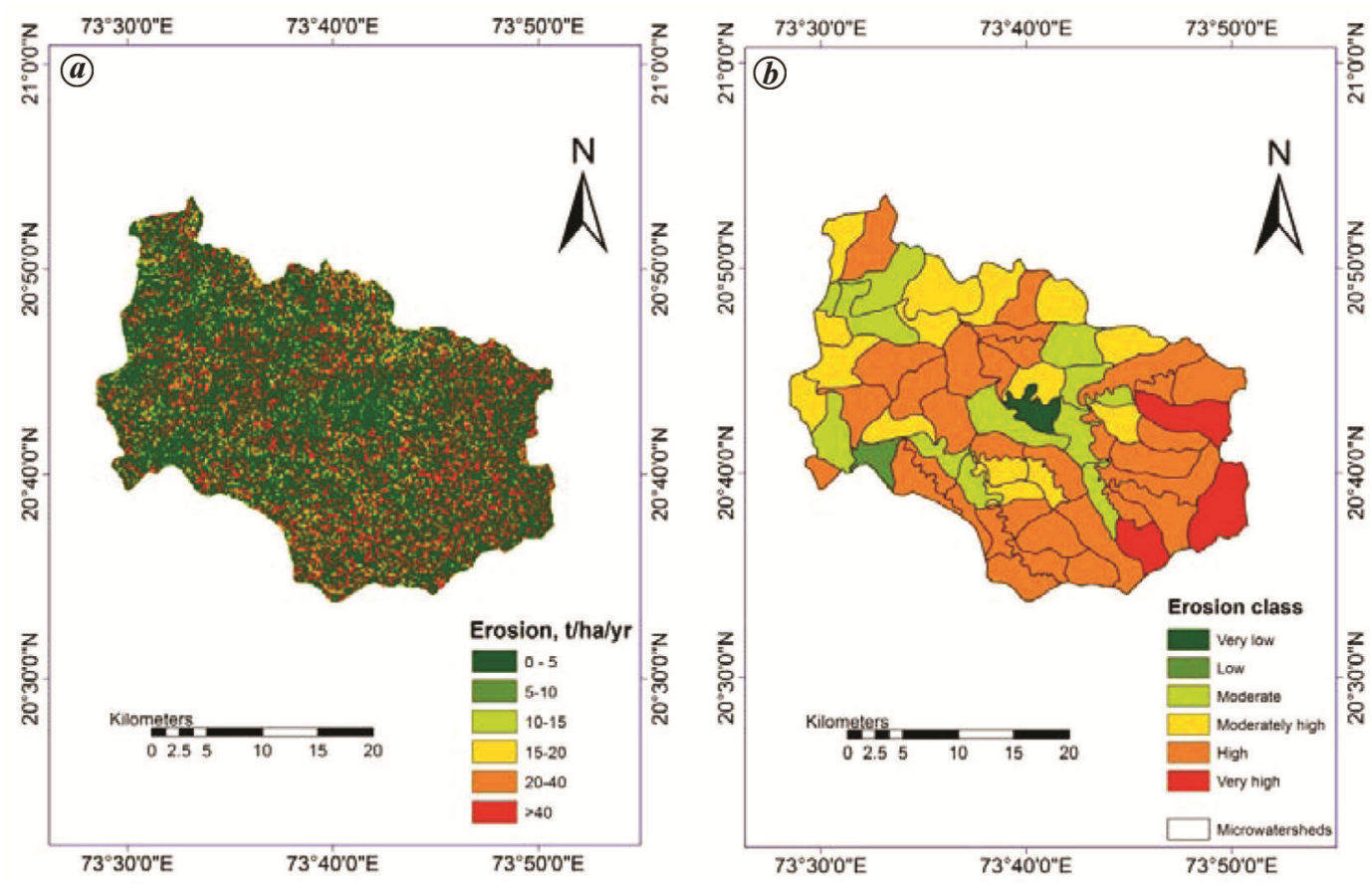

Figure 5. Soil erosion (a) and priority (b) of Ambika watershed.

priority class 1 has reduced from 3 to 0 , in priority class 2 from 32 to 22 and in priority class 3 it has reduced from 15 to 12 .

\section{Conclusion}

Quantitative assessment of soil loss using USLE and GIS in Ambika watershed was done to analyse the spatial distribution of soil erosion. The annual average soil loss for the entire watershed was estimated as 22.41 tonne $\mathrm{ha}^{-1}$ year $^{-1}$. A large portion of the watershed was affected by sheet and rill erosion resulting in low agricultural productivity. The use of contour bunds and terraces as soil conservation measures in areas with moderately high to very high soil erosion ( $>15$ tonne $\mathrm{ha}^{-1}$ year $^{-1}$ ) can reduce the annual average soil loss by $24 \%$. Therefore, these conservation measures can be effectively applied to Ambika watershed and other watersheds with similar geomorphology with slope ranging from $5 \%$ to $8 \%$, to reduce soil erosion. Hence, estimation of soil loss, understanding 


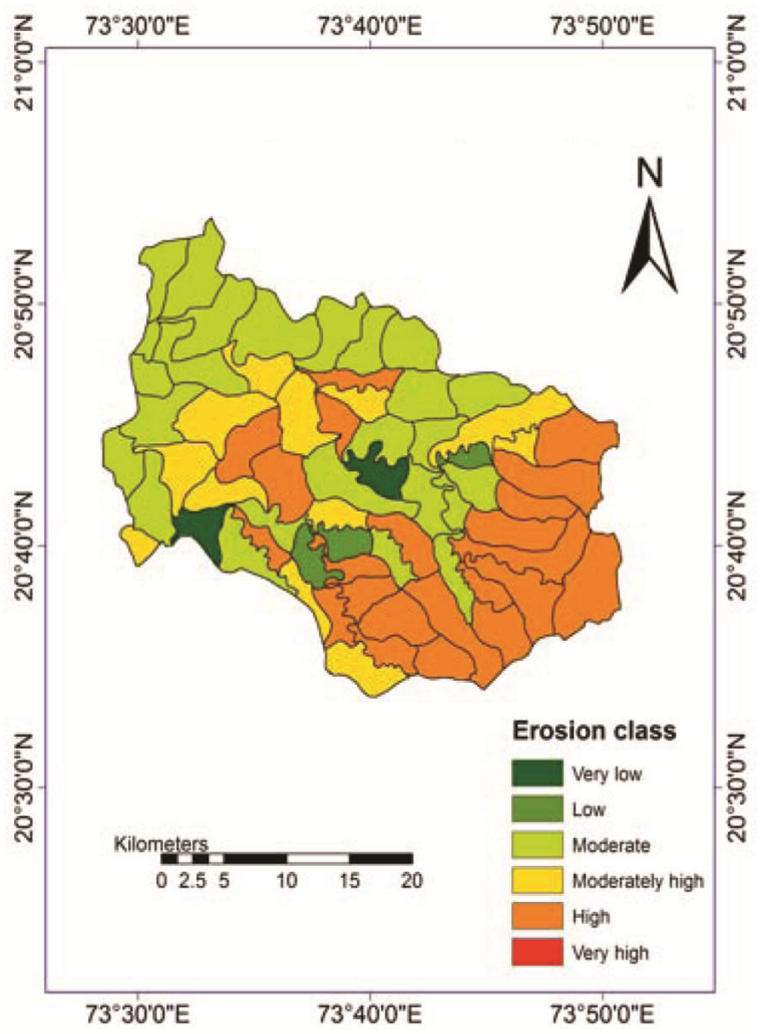

Figure 6. Soil erosion map of Ambika watershed after incorporating best management practices.

the causes of soil erosion, and planning and execution of conservation measures are essential for improving agricultural productivity and livelihood security.

1. Ni, S. X., Ma, G. B., Wei, Y. C. and Jiang, H. F., An indicator system for assessing soil erosion in the Loess Plateau gully regions: a case study in the Wangdonggou watershed of China. Pedosphere, 2004, 14, 37-44.

2. FAO and ITPS, Status of the world's soil resources (SWSR) main report. Food and Agriculture Organization of the United Nations and Intergovernmental Technical Panel on Soils, Rome, Italy, 2015.

3. Adgo, E., Teshome, A. and Mati, B., Impacts of long-term soil and water conservation on agricultural productivity: the case of Anjenie watershed, Ethiopia. Agric. Water Manage., 2013, 117, 55-61; doi:10.1016/j.agwat.2012.10.026.

4. Jaiswal, R. K., Thomas, T., Galkate, R. V., Ghosh, N. C. and Singh, S., Watershed prioritization using Saaty's AHP based decision support for soil conservation measures. Water Resour. Manage., 2014, 28, 475-494; doi:10.1007/s11269-013-0494-x.

5. Singh, G. and Panda, R. K., Grid-cell based assessment of soil erosion potential for identification of critical erosion prone areas using USLE, GIS and remote sensing: a case study in the Kapgari watershed, India. Int. Soil Water Conserv. Res., 2017, 5(3), 202211.

6. Quine, T. A. and Zhang, Y., An investigation of spatial variation in soil erosion, soil properties, and crop production within an agricultural field in Devon, United Kingdom. J. Soil Water Conserv., 2002, 57, 55-65.

7. Shinde, V. T., Sharma, A., Tiwari, K. N. and Singh, M., Quantitative determination of soil erosion and prioritization of micro- watersheds using remote sensing and GIS. J. Indian Soc. Remote Sensing, 2011, 39(2), 181-192; doi:10.1007/s12524-011-0064-8.

8. Welde, K., Identification and prioritization of subwatersheds for land and water management in Tekeze dam watershed, Northern Ethiopia. Int. Soil Water Conserv. Res., 2016, 4(1), 30-38.

9. Pandey, V. K., Panda, S. N., Raghuwanshi, N. S. and Sudhakar, S., Delineation and parameterization of Banikdih watershed using remote sensing and AVSWAT model. J. Indian Soc. Remote Sensing, 2006, 34(2), 143-152.

10. Misra, N., Satyanarayana, T. and Mukherjee, R. K., Effect of top elements on the sediment production rate from sub-watershed in upper Damodar Valley. J. Agric. Eng., 1984, 21(3), 65-70.

11. Bali, Y. P. and Karale, R. L., A Sediment Yield Index for Choosing Priority Basins, IAHS-AISH Publication No. 122, Paris, 1977, pp. 180-188.

12. Wischmeier, W. H. and Smith, D. D., Predicting Rainfall Erosion Losses-A Guide to Conservation Planning, United States Department of Agriculture, Washington, DC, USA, Agricultural Handbook No. 537, 1978.

13. Griffin, M. L., Beasley, D. B., Fletcher, J. J. and Foster, G. R., Estimating soil loss on topographically nonuniform field and farm units. J. Soil Water Conserv., 1988, 43, 326-331.

14. Alewell, C., Borrelli, P., Meusburger, K. and Panagos, P., Using the USLE: chances, challenges and limitations of soil erosion modelling. Int. Soil Water Conserv. Res., 2019, 7(3), 203-225; https://doi.org/10.1016/j.iswcr.2019.05.004.

15. Jain, S. K., Kumar, S. and Varghese, J., Estimation of soil erosion for a Himalayan watershed using GIS technique. Water Resour. Manage., 2001, 15, 41-54.

16. Jain, M. K. and Kothyari, U. C., Estimation of soil erosion and sediment yield using GIS. J. Hydrol. Sci., 2000, 45(5), 771-786.

17. Javed, A., Khanday, M. Y. and Ahmed, R., Prioritization of subwatersheds based on morphometric and land use analysis using 
remote sensing and GIS techniques. J. Indian Soc. Remote Sensing, 2009, 37, 261-274.

18. Mani, P. and Chakravorty, B., Remote sensing based sedimentation study of Maithon reservoir. J. Indian Soc. Remote Sensing, 2007, 35(1), 118-120.

19. Kadam, A. K., Jaweed, T. H., Kale, S. S., Umrikar, B. N. and Sankhua, R. N., Identification of erosion-prone areas using modified morphometric prioritization method and sediment production rate: a remote sensing and GIS approach. Geomat. Nat. Haz. Risk, 2019, 10(1), 986-1006.

20. Terranova, O., Antronico, L., Coscarelli, R. and Iaquinta, P., Soil erosion risk scenarios in the Mediterranean environment using RUSLE and GIS: an application model for Calabria (southern Italy). Geomorphology, 2009, 112, 228-245.

21. Renard, K. G., Foster, G. R., Weesies, G. A., McCool, D. K. and Yoder, D. C., Predicting Soil Erosion by Water: A Guide to Conservation Planning with the Revised Universal Soil Loss Equation (RUSLE), United States Department of Agriculture, Washington, DC, USA, USDA Agricultural Handbook No. 703, 1997.

22. Millward, A. A. and Mersey, J. E., Adapting the RUSLE to model soil erosion potential in a mountainous tropical watershed. Catena, 1999, 38, 109-129.

23. Choudhury, M. K. and Nayak, T., Estimation of soil erosion in Sagar Lake catchment of Central India. In Proceedings of the International Conference on Water and Environment, Bhopal, 2003, pp. 387-392.

24. Wischmeier, W. H., Johnson, C. B. and Cross, B. V., A soil erodibility nomograph from farmland and construction sites. J. Soil Water Conserv., 1971, 26, 189-193.
25. Haan, C. T., Barfield, B. J. and Hayes, J. C., Design Hydrology and Sedimentology for Small Catchments, Academic Press, New York, USA, 1994

26. USDA, Soil Survey Laboratory Methods Manual, Soil Survey Investigation Report No. 42, Version 4.0, USDA-Natural Resources Conservation Service, Lincoln, NE, USA, 2004.

27. Kayet, N., Pathak, K., Chakrabarty, A. and Sahoo, S., Evaluation of soil loss estimation using the RUSLE model and SCS-CN method in hill slope mining areas. Int. Soil Water Conserv. Res., 2018, 6, 31-42; https://doi.org/10.1016/j.iswcr.2017.11.002.

28. Pancholi, V. H., Lodha, P. P. and Prakash, I., Estimation of runoff and soil erosion for Vishwamitri River watershed, western India using RS and GIS. Am. J. Water Sci. Eng., 2015, 1(2), 7-14.

29. USDA, Handbook No. 282, Washington, DC, USA, 1981.

30. Dutta, D., Das, S., Kundu, A. and Taj, A., Soil erosion risk assessment in Sanjal watershed, Jharkhand (India) using geoinformatics, RUSLE model and TRMM data. Model. Earth Syst. Environ., 2015, 1(4), 1-9; http://dx.doi.org/10.1007/s40808-015-0034-1.

31. Klingbiel, A. A. and Montgomery, P. H., Land Capability Classification-Agriculture Handbook No. 210, Soil Conservation Service, USDA, Washington, DC, USA, 1961.

32. Murthy, V. V. N. and Jha, M. K., Land and Water Management Engineering, Kalyani Publishers, Ludhiana, 2011.

33. Walworth, J. L., Physical Contaminants, Environmental Monitoring and Characterization, Elsevier, USA, 2004.

Received 10 April 2020; accepted 1 June 2020

doi: $10.18520 / \mathrm{cs} / \mathrm{v} 119 / \mathrm{i} 6 / 984-991$ 